\title{
Can World Real Interest Rates Explain Business Cycles in a Small Open Economy?
}

\author{
William Blankenau ${ }^{\mathrm{a}}$ \\ M. Ayhan Kose ${ }^{\mathrm{b}}$ \\ $\mathrm{Kei}-\mathrm{Mu} \mathrm{Yi}{ }^{\mathrm{c}}$
}

\author{
July 1999 \\ Revised: November 1999
}

\begin{abstract}
While the world real interest rate is potentially an important mechanism for transmitting international shocks to small open economies, much of the recent quantitative research that studies this mechanism concludes that it has little effect on output, investment, and net exports. We re-examine the importance of world real interest rate shocks using an approach that reverses the standard real business cycle methodology. We begin with a small open economy business cycle model. But, rather than specifying the stochastic processes for the shocks, and then solving and simulating the model to evaluate how well these shocks explain business cycles, we use the model to back out the shocks that are consistent with the model's observable endogenous variables. Then we use variance decompositions to examine the importance of each shock. We apply this methodology to Canada and find that world real interest rate shocks can play an important role in explaining the cyclical variation in a small open economy. In particular, they can explain up to one-third of the fluctuations in output and more than half of the fluctuations in net exports and net foreign assets.
\end{abstract}

JEL Classification: F41, E32, D58.

Key Words: world interest rates, business cycles, dynamic stochastic general equilibrium models, small open economy.

\footnotetext{
*We thank Narayana Kocherlakota, Simon Potter, and two anonymous referees for helpful comments. We also benefited from the suggestions of seminar participants at Clark University, the 1999 Southeast International Economics Conference, and the 1999 Computing in Economics and Finance Conference. The views expressed in this paper are those of the authors and are not necessarily reflective of views at the Federal Reserve Bank of New York or the Federal Reserve System.

a Department of Economics, University of Wisconsin-Whitewater, 800 West Main Street, Whitewater, WI 531901790, e-mail: blankenw@uwwvax.uww.edu.

${ }^{\mathrm{b}}$ Graduate School of International Economics and Finance, Brandeis University, Waltham, MA 02454, e-mail: akose@ lemberg.brandeis.edu.

${ }^{c}$ Corresponding Author: International Research, Federal Reserve Bank of New York, 33 Liberty St., New York, NY 10045, e-mail: Kei-Mu.Yi@ny.frb.org
} 


\section{Introduction}

In theory, the world real interest rate is an important mechanism by which foreign shocks are transmitted to small open economies. Changes in the world real interest rate can affect behavior along many margins: they affect households by generating intertemporal substitution, wealth, and portfolio allocation effects, and they affect firms by altering incentives for domestic investment. It is surprising, then, that much of the recent quantitative research on the effects of world real interest rates find that they are not important in explaining the dynamics of small open economies. This literature (see for example, Mendoza, 1991, Correia, Neves, and Rebelo, 1992, 1995, and Schmitt-Grohe, 1998) finds that world real interest rate shocks have small effects on output, consumption, and labor hours - and in some cases - even on investment, net exports, and net foreign assets.

In obtaining these findings, the authors mentioned above follow the standard international real business cycle approach. They build a dynamic stochastic model of a small open economy. Then they parameterize the model, including the processes for the stochastic shocks - one of which is the world real interest rate. Finally, they solve the model and/or conduct impulse responses to quantitatively evaluate the role of interest rate shocks.

There are, however, three difficulties with this standard approach. First, there is no consensus on a good proxy for the ex ante world real interest rate, which is, of course, unobservable. ${ }^{1}$ A wide variety of nominal interest rates, price indices, and inflation expectations have been used to construct measures of world real interest rates. For example, the 3-month U.S. T-Bill rate, the rate of return on the S\&P 500, the LIBOR rate, as well as a weighted average of several countries' T-Bill rates, have been employed as nominal interest rates, for example. ${ }^{2}$ These different measures are not necessarily highly correlated with each other, as Table 1 shows for four ex ante real interest rates constructed from the same price index and inflation

\footnotetext{
${ }^{1}$ Obstfeld and Rogoff (1995, p. 1781), in discussing tests of intertemporal current account models, note that "a first difficulty is that it is not obvious what real interest rate to use to discount expected future output flows." Indeed, studying interest rates in a real business cycle context is a relatively recent phenomenon. King, Plosser, and Rebelo (1988, p. 226) do not "study interest rates because of the well-known difficulties of obtaining measures of expected real interest rates". Beaudry and Guay (1996) and van Wincoop (1993) are among the first to focus explicitly on comparing interest rates implied by real business cycle models to interest rates constructed from the data.

${ }^{2}$ Mendoza (1991), Schmitt-Grohe (1998), van Wincoop (1993), Beaudry and Guay (1996), and Barro and Sala-iMartin (1990) use the U.S. and other countries' 3-month T-bill rate. Schmitt-Grohe (1998) and Correia, Neves, and Rebelo (1992, 1993) use the S\&P 500 index. Gagnon and Unferth (1996) use the Euro-market interest rates on certificates of deposit. Kose (1998) and Senhadji (1998) use the LIBOR rate. With respect to prices, van Wincoop (1993) and Barro and Sala-i-Martin (BSM) (1990) use the CPI, Beaudry and Guay (1996) use the GNP deflator, and Schmitt-Grohe (1998) uses the GDP deflator. For modeling inflation expectations, the Livingston Survey, as well as many ARMA specifications have been employed.
} 
expectations, but with different nominal interest rates. Half of the correlations are less than 0.25. Second, as discussed extensively in Ingram, Kocherlakota, and Savin (IKS) (1994a, 1994b, 1997) models in which the number of unobservable exogenous shocks is less than the number of observable endogenous variables imply that some of the observable variables are related deterministically. This feature exists in many small open economy models, and is fundamentally inconsistent with the data. The models are singular, which implies that it is not possible to back out a unique realization of unobservable exogenous shocks. In such models, there are an infinity of ways in which the importance of shocks - even orthogonal shocks - in driving business cycles can be calculated. Finally, in any model with multiple shocks, it is possible to determine the impact of any single shock only by imposing often-arbitrary identification restrictions. For example, one often-imposed restriction in models of small open economies is that domestic shocks are uncorrelated with the world interest rate. Baxter and Crucini (1993, p. 432) find that this assumption is "empirically indefensible." At best, then, only a range of estimates corresponding to different identification orderings of the shocks - can be obtained on the importance of world interest rate shocks.

The purpose of this paper is to pursue an alternative quantitative methodology to assessing the importance of world real interest rates on small open economies. We continue to employ a standard dynamic stochastic small open economy model, (augmented to include preference and depreciation shocks). However, rather than parameterizing a shock process and using the model to solve for the endogenous variables, we let the model and the endogenous variables tell us the exogenous shocks - including the world real interest rate - that are consistent with the model. Specifically, we use the model's Euler equations, data on the model's endogenous variables, as well as estimated decision rules for the capital stock and net foreign assets, to recover the exogenous shocks implied by the model and the data. ${ }^{3}$ Then, to compute the importance of these backed-out shocks in driving business cycles, we perform variance

\footnotetext{
${ }^{3}$ Our methodology draws from work by Ingram, Kocherlakota, and Savin (1994a, 1994b), Hall (1986), Parkin (1988), and Lee (1996), among others. Ingram, Kocherlakota, and Savin (IKS) (1994a) back out exogenous shocks of a nonsingular closed economy real business cycle model to examine the importance of the productivity shocks. To study the cyclical behavior of home production IKS (1997) generate realizations of market and non-market hours. Using a similar methodology, Baxter and King (1998) back out the realizations of productivity and preference shocks, and Ambler and Paguet (1994) back out the time series of depreciation shocks. Smith and Zin (1997) estimate the policy functions in a closed economy real business cycle model to generate realizations of output, consumption, and employment. There are other approaches to resolving the singularity problem. In order to ensure that the number of unobservable exogenous shocks equals the number of observable endogenous variables, measurement error can be added. See, for example, McGrattan (1994).
} 
decompositions. By altering the ordering of the shocks, we generate a range of estimates on the importance of each of the shocks.

To a large extent, then, our methodology reverses the standard approach. Moreover, our approach deals with all three difficulties highlighted above. First, we avoid the problems associated with calculating the appropriate world real interest rate; our backed-out interest rate measures are consistent with the model and the data. Second, because our model is nonsingular, we can evaluate the importance of the world real interest rate in businesses cycles without violating any relationships implied by the model. Third, by using shocks that are consistent with the model and by examining all possible orderings of shocks we do not need to take a particular stand on the relationship between them nor on their orthogonality.

We apply our methodology to quarterly Canadian data from 1961:1 to 1996:4. Our backed-out world real interest rate measure is quite different from proxies constructed from the data. Our variance decompositions indicate that world real interest rate shocks can play a significant role in explaining Canadian business cycle fluctuations. If world interest rates shocks are ordered first, they explain 33\% of Canada's output variation. They can also account for a significant fraction of variation in Canada's external balances: up to 62\% (57\%) of the variation in net exports (net foreign assets) is explained by these shocks. These quantitative findings contrast sharply with the results of Mendoza (1991) and Schmitt-Grohe (1998). However, their results are qualitatively similar to our findings, and they are quantitatively similar to the variance decomposition results we obtain when real interest rates are ordered last.

The rest of this paper is organized as follows: in section 2, we present our dynamic stochastic small open economy model. In section 3, we calibrate the model to Canada and present our methodology on recovering the exogenous shocks. Our results are presented in section 4, and section 5 concludes.

\section{The Model}

Our model is based on the standard small open economy real business cycle model. ${ }^{4}$ The representative household maximizes expected lifetime utility given by:

\footnotetext{
${ }^{4}$ Mendoza (1991) was the first small open economy real business cycle model. See also Correia, Neves, and Rebelo (1992, 1995), Schmitt-Grohe (1998), Lee (1996), Sadka and Yi (1996), Kose (1998), and Senhadji (1998) for the use of dynamic small open economy models in evaluating the roles of different shocks. Similar models have been used extensively in the literature on the intertemporal approach to current account behavior. See Baxter (1995) for a survey of dynamic general equilibrium business cycle models of open economies and their use in studying the sources and transmission of international business cycles.
} 


$$
E_{0} \sum_{t=0}^{\infty} \beta^{t} \frac{\left[c_{t}^{\eta_{\theta} \theta} l_{t}^{1-\theta}\right]^{1-\gamma}-1}{1-\gamma}
$$

where $c_{t}$ is consumption in period $t, l_{t}$ is leisure, $\eta_{t}$ is a time-varying preference shock, $\theta$ is the consumption share parameter, $\beta$ is the discount factor, and $\gamma$ is the household's coefficient of relative risk aversion. ${ }^{5}$

The economy produces an internationally tradable good, $\mathrm{y}_{\mathrm{t}}$, according to:

$$
y_{t}=z_{t} k_{t}^{\alpha} n_{t}^{1-\alpha}, 0<\alpha<1
$$

where $k_{t}$ is the domestic capital stock at the beginning of the period $t, n_{t}=1-l_{t}$ is labor hours, $\alpha$ governs the share of income accruing to capital, and $\mathrm{z}_{\mathrm{t}}$ is the technology shock.

Following Baxter and Crucini (1993), we specify the following law of motion for capital:

$$
k_{t+1}=\left(1-\delta_{t}\right) k_{t}+\phi\left(\frac{i_{t}}{k_{t}}\right) k_{t}
$$

where $\mathrm{i}_{\mathrm{t}}$ is investment, $\delta_{t}$ is an exogenous depreciation shock, and $\phi($.$) represents the standard$ adjustment cost function, with $\phi()>0,. \phi(.)^{\prime}>0$, and $\phi(.)^{\prime \prime}<0$.

The representative household has access to world capital markets to borrow and lend foreign financial assets. Net foreign assets, $A_{t}$, evolve according to:

$$
A_{t+1}=n x_{t}+\left(1+r_{t}\right) A_{t}
$$

where $\mathrm{nx}_{\mathrm{t}}$ is net exports measured in units of the domestic consumption good, and $\mathrm{r}_{t}$ is the exogenously determined stochastic risk-free real interest rate from period t- 1 to $t$. To prevent the representative household from playing a Ponzi game, we impose the condition:

$$
\lim _{t \rightarrow \infty} E_{0}\left(A_{t+1} \frac{1}{\left(1+r_{t}\right)^{t}}\right)=0
$$

Finally, the aggregate resource constraint is:

$$
c_{t}+i_{t}+n x_{t} \leq y_{t} .
$$

\footnotetext{
${ }^{5}$ Note that we use a constant discount factor, rather than the endogenous discount factor in Mendoza (1991) and Schmitt-Grohe (1998). Endogenous discount factors are used to ensure that models of small open economies have a stationary stochastic steady state. However, our approach does not require us to solve for the model's steady-state or for the dynamics around the steady-state. Moreover, because Correia, Neves, and Rebelo $(1992,1995)$ use a constant discount factor, the result that interest rates are not important is apparently robust to the type of discount
} 
In our model there are four exogenous shocks, the world real interest rate and a technology shock - which are the shocks in Mendoza's model - as well as a preference shock and a depreciation shock. ${ }^{6}$ Because our model has four observable endogenous variables, (consumption, investment, labor hours, and net exports) we need four exogenous shocks to insure that the model is non-singular. Singular models, that is, models with fewer exogenous unobservable variables than endogenous observable variables, imply deterministic relationships between the observable variables. These relationships are clearly violated in the data (whenever the variance-covariance matrix of the data is non-singular). ${ }^{7}$

We substitute (2) into (6), and substitute the resulting expression for net exports into (4). The representative household, then, maximizes:

$$
\begin{gathered}
\max E_{0} \sum_{t=0}^{\infty} \beta^{t} \frac{\left[c_{t}^{\eta_{t} \theta} l_{t}^{1-\theta}\right]^{1-\gamma}-1}{1-\gamma} \\
\text { subject to } \\
\mathrm{c}_{\mathrm{t}}+\mathrm{i}_{\mathrm{t}}+\mathrm{A}_{\mathrm{t}+1}-\left(1+\mathrm{r}_{\mathrm{t}}\right) \mathrm{A}_{\mathrm{t}} \leq \mathrm{z}_{\mathrm{t}} \mathrm{k}_{\mathrm{t}}^{\alpha} \mathrm{n}_{\mathrm{t}}^{1-\alpha} \\
k_{t+1}=\left(1-\delta_{t}\right) k_{t}+\phi\left(\frac{i_{t}}{k_{t}}\right) k_{t}
\end{gathered}
$$

where $\lambda_{1 \mathrm{t}}$ and $\lambda_{2 \mathrm{t}}$ are the LaGrange multipliers. The first order conditions are:

$$
\begin{aligned}
& c_{t}: \eta_{t} \theta c_{t}^{\eta_{t} \theta(1-\gamma)-1}\left(1-n_{t}\right)^{(1-\theta)(1-\gamma)}-\lambda_{1 t}=0 \\
& \mathrm{n}_{\mathrm{t}}:-\mathrm{c}_{\mathrm{t}}^{\eta_{\mathrm{t}} \theta(1-\gamma)}(1-\theta)\left(1-\mathrm{n}_{\mathrm{t}}\right)^{(1-\theta)(1-\gamma)-1}+\lambda_{1 \mathrm{t}} \mathrm{z}_{\mathrm{t}} \mathrm{k}_{\mathrm{t}}^{\alpha}(1-\alpha) \mathrm{n}_{\mathrm{t}}^{-\alpha}=0 \\
& \mathrm{i}_{\mathrm{t}}:-\lambda_{1 \mathrm{t}}+\frac{\partial \phi}{\partial \mathrm{i}_{\mathrm{t}}} \lambda_{2 \mathrm{t}}=0
\end{aligned}
$$

factor. This latter inference is consistent with Kim and Kose (1999), who show that a model with a fixed discount factor generates similar business cycle implications to one with an endogenous discount factor.

${ }^{6}$ Our shocks are the same as those in Lee (1996). Stockman and Tesar (1995) employ preference shocks in a twocountry business cycle model. Ambler and Paguet (1994) employ depreciation shocks in a closed economy real business cycle model. Greenwood, Hercowitz, and Huffman (1988) study a model where the marginal efficiency of investment is a stochastic shock that is similar to the depreciation shocks we consider here.

${ }^{7}$ IKS state that "using a singular model when the variance-covariance matrix of the data is nonsingular is equivalent to solving a set of inconsistent linear equations; there is no solution." (IKS, 1994a, p. 416) 


$$
\begin{aligned}
& \mathrm{k}_{\mathrm{t}+1}:-\lambda_{2 \mathrm{t}}+\beta \mathrm{E}_{\mathrm{t}}\left[\lambda_{1 \mathrm{t}+1} \alpha \frac{\mathrm{y}_{\mathrm{t}+1}}{\mathrm{k}_{\mathrm{t}+1}}+\lambda_{2 \mathrm{t}+1}\left\{\phi\left(\frac{\mathrm{i}_{\mathrm{t}+1}}{\mathrm{k}_{\mathrm{t}+1}}\right)-\frac{\mathrm{i}_{\mathrm{t}+1}}{\mathrm{k}_{\mathrm{t}+1}} \frac{\partial \phi}{\partial \mathrm{k}_{\mathrm{t}+1}}+\left(1-\delta_{\mathrm{t}+1}\right)\right\}\right]=0 \\
& \mathrm{~A}_{\mathrm{t}+1}:-\lambda_{1 \mathrm{t}}+\beta \mathrm{E}_{\mathrm{t}}\left[\lambda_{1 \mathrm{t}+1}\left(1+\mathrm{r}_{\mathrm{t}+1}\right)\right]=0
\end{aligned}
$$

Equations (7) and (8) yield:

$$
\frac{(1-\alpha) y_{t}}{n_{t}}=\frac{c_{t}}{\left(1-n_{t}\right)} \frac{(1-\theta)}{\eta_{t} \theta}
$$

and equations (9) and (10) yield:

$$
\varphi_{t} \lambda_{1 t}=\beta E_{t}\left[\lambda_{1 t+1} \alpha \frac{y_{t+1}}{k_{t+1}}+\varphi_{t+1} \lambda_{1 t+1}\left\{\phi\left(\frac{i_{t+1}}{k_{t+1}}\right)-\frac{i_{t+1}}{k_{t+1}} \frac{\partial \phi}{\partial k_{t+1}}+\left(1-\delta_{t+1}\right)\right\}\right]
$$

where $\varphi_{t}=\left(\frac{\partial \phi}{\partial i_{t}}\right)^{-1}$

Equation (11) governs the dynamics of net foreign assets. Equation (12) equates the marginal rate of substitution between consumption and leisure to the marginal product of labor. Equation (13) is the intertemporal efficiency condition pertaining to the domestic capital stock.

\section{Recovering the Exogenous Shocks}

\subsection{Parameter Calibration}

We calibrate our structural parameters to correspond to the existing real business cycle literature. Following Backus, Kehoe, and Kydland (1992), the consumption share parameter, $\theta$, is set to 0.34 , which is consistent with allocating, on average, 30 percent of the endowment of non-sleeping time to labor market activities. The risk aversion parameter, $\gamma$, is set to 1.5; this is an intermediate value between the commonly used values of 2 and 1 (logarithmic utility). Following Mendoza (1991) and Schmitt-Grohe (1998), the share of capital income in the production, $\alpha$, is set to 0.32 . The discount factor and the initial value of the depreciation shock are set to 0.988 and 0.025 , respectively; both values are widely employed in real business cycle models calibrated to quarterly data. (See, for example, King, Plosser and Rebelo, 1988).

We specify the following functional form for the adjustment cost function:

$$
\phi\left(\frac{i}{k}\right)=\omega_{1}\left(\frac{i}{k}-\omega_{2}\right)^{\omega_{3}}
$$


The adjustment cost parameters $\omega_{1}, \omega_{2}$, and $\omega_{3}$ are chosen so that the initial equilibrium of the model is the same as that without adjustment costs. This implies that $\phi(\mathrm{i} / \mathrm{k})=\mathrm{i} / \mathrm{k}$ and $\phi(\mathrm{i} / \mathrm{k})^{\prime}=1$. In addition, $\phi(\mathrm{i} / \mathrm{k})^{\prime \prime}$ is set so that the elasticity of the marginal adjustment cost function, $\xi=-\left(\phi^{\prime} / \phi^{\prime \prime}\right)(\mathrm{i} / \mathrm{k})^{-1}$, is equal to 15 . This is the benchmark value used by Baxter and Crucini (1993). Together, these three conditions determine the values of $\omega_{1}, \omega_{2}$, and $\omega_{3}$. We examine the sensitivity of our results to different parameterizations in section 4 .

\subsection{Solving for the Shocks}

The standard real business cycle approach involves calibrating the model's parameters, specifying forcing processes of the exogenous shocks, and then solving the model. The model's solution would then be used to derive the first and second moments of interest, calculate impulse responses, or compute variance decompositions. Our approach reverses this methodology: rather than produce simulated time series for endogenous variables, we use the observable endogenous variables and the orthogonality conditions implied by the Euler equations to recover the exogenous shocks $\left\{\mathrm{r}_{\mathrm{t}}, \mathrm{z}_{\mathrm{t}}, \eta_{\mathrm{t}}, \delta_{\mathrm{t}}\right\}$ consistent with the endogenous variables.

We treat consumption, investment, labor hours, and net exports as observable; however, we treat the two endogenous state variables, $\mathrm{k}_{\mathrm{t}}$ and $\mathrm{A}_{\mathrm{t}}$, as unobservable. ${ }^{8}$ To solve for these two variables, we estimate the policy functions for capital and net foreign assets. We specify the following approximate policy functions $k_{t+1}=k^{*}\left(s_{t}, \psi_{1}\right)$ and $A_{t+1}=A^{*}\left(s_{t}, \psi_{2}\right)$ :

$$
\begin{aligned}
& \ln \left(\mathrm{k}_{\mathrm{t}+1}\right)=\psi_{11}+\psi_{12} \ln \left(\mathrm{c}_{\mathrm{t}}\right)+\psi_{13} \ln \left(\eta_{\mathrm{t}}\right)+\psi_{14} \ln \left(\mathrm{z}_{\mathrm{t}}\right)+\psi_{15} \ln \left(\mathrm{k}_{\mathrm{t}}\right)+\psi_{16} \delta_{\mathrm{t}-1} \\
& \mathrm{~A}_{\mathrm{t}+1}=\psi_{21} \ln \left(\mathrm{c}_{\mathrm{t}}\right)+\psi_{22} \mathrm{r}_{\mathrm{t}-1}+\psi_{23} \ln \left(\mathrm{z}_{\mathrm{t}}\right)+\psi_{24} \ln \left(\eta_{\mathrm{t}}\right)+\psi_{25} \delta_{\mathrm{t}}+\psi_{26} \ln \left(\mathrm{i}_{\mathrm{t}}\right)
\end{aligned}
$$

As in Lee (1996), we choose approximate policy functions that are computationally convenient and include most of the relevant state variables. ${ }^{9}$ The effect of additional lagged variables is accounted for by the inclusion of $c_{t}$. The exclusion of the world real interest rate in the policy

\footnotetext{
${ }^{8}$ While data on these two variables exist, we believe these data, because they are calculated as accumulated flows, are poor counterparts to the concepts of capital and net foreign assets. In the case of capital, investment flows are typically accumulated using depreciation rates that are assumed constant across different types of capital and over time. Also, no valuation adjustments are typically made. In the case of net foreign assets, valuation adjustments are made, but different adjustments produce different numbers. According to the Bureau of Economic Analysis, depending on whether current cost valuation or market valuation is used, the U.S. net foreign asset (investment) position at yearend 1998 was $-\$ 1.2$ trillion or $-\$ 1.5$ trillion. Moreover, the net investment income from the U.S. position was only about $-\$ 7$ billion, which implies either that the $\$ 4.9$ trillion in U.S. assets abroad were earning a considerably higher rate of return than the $\$ 6.2$ trillion foreign assets in the U.S., or that the asset stocks were poorly measured.

${ }^{9}$ We experimented with several policy functions to assess the sensitivity of our results to changes in functional forms. These changes have little effect on our main findings.
} 
function for capital allows us to decrease the dimensionality of the problem; we are able to estimate $\psi_{1}$ and $\psi_{2}$ sequentially, rather than simultaneously.

Replacing $\mathrm{k}_{\mathrm{t}+1}$ and $\mathrm{A}_{\mathrm{t}+1}$ with our approximate policy functions, we estimate the sample analogs of (13) and (11) given below:

$$
\begin{aligned}
& \frac{1}{T} \sum_{i=1}^{T}\left(\frac{\beta}{\lambda_{2 t}}\left[\lambda_{1 t+1} \alpha \frac{y_{t+1}}{k_{t+1}}+\lambda_{2 t+1}\left\{\phi\left(\frac{i_{t+1}}{k_{t+1}}\right)-\frac{i_{t+1}}{k_{t+1}} \frac{\partial \phi}{\partial k_{t+1}}+\left(1-\delta_{t+1}\right)\right\}\right]\right) Z_{1 t}=1 \\
& \frac{1}{T} \sum_{i=1}^{T} \beta\left[\frac{\lambda_{1 t}}{\lambda_{1 t-1}}\left(\frac{A_{t+1}-n x_{t}}{A_{t}}\right)\right] Z_{2 t}=1 \\
& \text { where } \lambda_{1 t}=\frac{c_{t}^{\eta_{t} \theta(1-\gamma)}(1-\theta)\left(1-n_{t}\right)^{(1-\theta)(1-\gamma)-1} n_{t}}{y_{t}(1-\alpha)} \text { and } \lambda_{2 t}=\lambda_{1 t}\left(\frac{\partial \phi}{\partial i_{t}}\right)^{-1}
\end{aligned}
$$

$\mathbf{Z}_{1 \mathrm{t}}$ and $\mathbf{Z}_{2 \mathrm{t}}$ are $\left(\mathrm{p}_{1} \mathrm{x} 1\right)$ and $\left(\mathrm{p}_{2} \mathrm{x} 1\right)$ vectors of instruments. We employ a generalized method of moments estimator (GMM) to estimate the parameters $\psi_{1}$ from equation (14) and $\psi_{2}$ from equation $(15) .{ }^{10}$ Our instrument vectors are:

$$
\begin{aligned}
& Z_{1 t}=\left\lfloor 1, \varepsilon_{1, t-1}, \varepsilon_{1, t-2}, \hat{c}_{t}, \hat{c}_{t-1}, \hat{\eta}_{t}, \hat{\eta}_{t-1}, \hat{z}_{t}, \hat{z}_{t-1}, \delta_{t}, \delta_{t-1}, \hat{h}_{t}, \hat{h}_{t-1}, n x_{t}\right\rfloor \\
& Z_{2 t}=\left\lfloor 1, \varepsilon_{2, t-1}, \varepsilon_{2, t-2}, \hat{c}_{t}, \hat{c}_{t-1}, \hat{c}_{t-2}, \hat{\eta}_{t}, \hat{\eta}_{t-1}, \hat{z}_{t}, \hat{z}_{t-1}, \delta_{t}, \delta_{t-1}, \hat{h}_{t}, \hat{h}_{t-1}\right\rfloor
\end{aligned}
$$

where $\hat{c}_{t}$ is the growth rate of $c$ in period $t$ and where $\varepsilon_{1, t-1}$ and $\varepsilon_{2, t-1}$ are the lagged error terms from the estimation.

From the estimated policy functions, our model's equations, and initial values $\mathrm{k}_{0}, \mathrm{~A}_{0}, \delta_{-1}$, and $r_{0}$, we can recover the shocks $\left\{r_{t}, z_{t}, \eta_{t}, \delta_{t}\right\} .{ }^{11}$ Equation (12) above identifies the series of preference shocks $\left(\eta_{t}\right)$. To obtain the other shocks as well as our estimates for $k_{t+1}$ and $A_{t+1}$, we employ equations (2), (3), and (4) and our estimated policy functions $\mathrm{k}^{*}\left(\mathrm{~s}_{\mathrm{t}}, \psi_{1}\right)$ and $\mathrm{A}^{*}\left(\mathrm{~s}_{\mathrm{t}}, \psi_{2}\right)$. For example, from equation (2) and the initial $\mathrm{k}_{0}$, we obtain $\mathrm{z}_{0}$. We can then back out $\mathrm{k}_{1}$ from the estimated policy function, and we use $\mathrm{k}_{1}$ to obtain $\mathrm{z}_{1}$, and so forth.

\subsection{Data}

\footnotetext{
${ }^{10}$ In addition to Lee (1996), Smith and Zin (1997) and Beauchemin (1996) specify approximate policy functions and then estimate them by GMM.

${ }^{11} \mathrm{~K}_{0}$ is set by assuming the steady-state version of (3) and using data on investment. $\mathrm{r}_{0}$ equals $1 / \beta-1$ and $\delta_{-1}$ is set to 0.025. $\mathrm{A}_{0}$ is set by assuming the steady-state version of (4) holds for 1961:1. We truncate the first 8 data points from the recovered shocks so that the remaining part of the series is less sensitive to our choice of starting values.
} 
Seasonally adjusted quarterly values of consumption, investment, and net exports for Canada from 1961:1 to 1996:4 are drawn from the IMF's International Financial Statistics (IFS) national account series. Consumption is household consumption expenditures; investment is the sum of gross capital formation and inventory adjustments; net exports is the difference between exports and imports of goods and services. Output, $\mathrm{y}_{\mathrm{t}}$, is the sum of $\mathrm{c}_{\mathrm{t}}, \mathrm{i}_{\mathrm{t}}$ and $\mathrm{nx}_{\mathrm{t} \cdot}{ }^{12}$ We convert these data to real per capita values by using the GDP deflator (1990 prices) from the IFS and population data drawn from the Bank of International Settlements database. Seasonally adjusted quarterly labor hours and civilian employment data are drawn from the OECD. ${ }^{13}$ Following King, Plosser and Rebelo (1988) total hours worked, $\mathrm{n}_{\mathrm{t}}$, is defined as the product of hours worked per week in the manufacturing sector and the employment rate normalized by the weekly time endowment.

\section{Results}

In this section, we first examine the properties of our backed out shocks. In so doing, we provide some economic intuition on how our model works. We also compare our backed out interest rate series with measures constructed from the data. Finally, we examine the relative importance of our four exogenous shocks in inducing business cycles in Canada.

\subsection{Properties of the Exogenous Shocks}

The coefficients from estimating equations (14) and (15) and their associated standard errors are given in Table 2. Because the number of instruments exceeds the number of estimated parameters, we are able to conduct a test of the over-identifying restrictions. For each equation, the null hypothesis that the over-identifying restrictions are satisfied is not rejected at the $10 \%$ significance level.

Figure 1 plots the four backed-out exogenous shocks and Table 3 presents volatility and co-movement properties of these shocks. ${ }^{14}$ They show that the world real interest rate is the most volatile of the four shocks, with a standard deviation 1.5 times larger than that of the

\footnotetext{
${ }^{12}$ In our model, there is no role for government expenditures. Hence, following Watson (1991), King, Plosser, Stock, and Watson (1991), and Beaudry and Guay (1996), we exclude government expenditures from our measure of aggregate output.

${ }^{13}$ The labor hours data is manufacturing hours worked per week, and is drawn from the OECD's Main Economic Indicators. The civilian employment data is drawn from the OECD Statistical Compendium on CD-ROM. This data is seasonally adjusted from 1965:1 to 1996:4. We impute the seasonally adjusted data for 1964:4 by multiplying the reciprocal of the 4-quarter growth rate from 1964:4 to 1965:4 of the non-seasonally adjusted employment level by the 1965:4 seasonally adjusted employment level, and similarly for 1964:3, 1964:2, ,.,1961:1.

${ }^{14}$ Following the standard practice in the real business cycle literature, we detrend the series using Hodrick and Prescott (HP) (1997) filter.
} 
depreciation shock and about 8 times larger than that of the preference and technology shocks. ${ }^{15}$ Table 3 also shows that the correlation coefficient of the world real interest rate shock with the technology shock and the depreciation shock is 0.38 and -0.32 , respectively. These correlations are consistent with the findings in Baxter and Crucini (1993). In their two-country model calibrated to represent a large economy and a small economy, they find that fluctuations in the world real interest rate are correlated with domestic shocks.

Correlations between our shocks and macroeconomic variables are presented in Table 4. We focus on the correlations involving the world real interest rate. The correlation between output and the world real interest rate is 0.24 . We noted earlier that the technology shock and the world real interest rate shock are positively correlated. This helps explain why a positive correlation between output and the world real interest rate shock can be generated. There is also a positive correlation (0.52) between the world real interest rate shock and net exports. All else equal, higher real interest rates imply more savings and less investment, leading to greater net exports. The technology shocks are not persistent; hence, the positive correlation between the world interest rate and technology shocks is probably not strong enough to induce changes in savings and investment to completely offset the direct effect of the higher interest rate. Finally, the correlation between the real interest rate and consumption is positive largely because world interest rate shocks are positively correlated with domestic productivity shocks.

We examine the sensitivity of our results with respect to changes in the parameters of the model. In particular, we study whether the results in Tables 3 and 4 are robust to changes in the risk aversion coefficient, the discount factor, the elasticity of the marginal adjustment cost, and the share of capital income in total output. In general, we find our results to be quite robust. For example, changes in the parameters do not affect the signs of the correlations between the world real interest rate and output: interest rates are always weakly procyclical. While changes in the parameters affect the volatility of the shocks, their effects on the co-movement properties of the shocks are quite small.

It is worth comparing some of the properties of our interest rate measures with the properties of alternative measures. Table 5 presents comparisons involving the four ex ante

\footnotetext{
${ }^{15}$ From Figure 1.2, we see that the depreciation shocks are highly variable and occasionally negative. See Ambler and Paquet (1994) and Ingram, Kocherlakota, and Savin (1994a) for a discussion of occasionally negative depreciation and highly variable depreciation rates. They argue that a composite capital series represents many highly substitutable capital goods whose marginal productivies need not move together. Thus, there is substitution across capital types with fixed but differing depreciation rates and the composite depreciation rate can be highly variable.
} 
interest rates presented in Table 1. While the volatility of our interest rate measure is similar to the other measures, there is very little correlation between the other measures and our measure. ${ }^{16}$ Also, the alternative interest rate measures tend to be negatively correlated with output, but our model-generated interest rate is positively correlated with output. This finding is the same as in Beaudry and Guay's (1996) closed economy framework. However, the correlations with net exports and investment tend to be broadly similar across the different interest rate measures. Summarizing, our interest rate shock differs from the alternative measures on two important dimensions, but the co-movement properties correspond to basic economic intuition.

\subsection{Importance of Shocks in Business Cycle Fluctuations}

In a multi-shock model, measuring the contribution of any single shock to business cycle fluctuations is difficult because the shocks are correlated with each other, as we have shown for Canada. The standard approach in the RBC literature, which examines each shock in isolation from the other shocks, can then yield misleading inferences. Our approach is to apply a variance decomposition method analogous to what is employed in the vector autoregression (VAR) literature. ${ }^{17}$ Following the usual VAR setting, we perform variance decompositions in our framework by imposing a recursive ordering scheme that generates orthogonal shocks from the correlated shocks. ${ }^{18}$ Because the order of precedence of the shocks is crucial to determining the shocks' relative importance in explaining the variance of a particular macroeconomic variable, and because we have little prior information on which ordering to employ, we compute the contribution of each shock for all possible orderings (24).

To illustrate, let $\left[\hat{r}_{t}, \hat{z}_{t}, \hat{\delta}_{t}, \hat{\eta}_{t}\right] \mathrm{t}=1$, T, denote the vector of time series of our four shocks. The ordering $\left[\hat{r}_{t}, \hat{z}_{t}, \hat{\delta}_{t}, \hat{\eta}_{t}\right]$ indicates that the real interest rate is first in precedence - any contemporaneous correlation between $\hat{r}_{t}$ and the other shocks is "assigned" to $\hat{r}_{t}-$ and the

\footnotetext{
${ }^{16}$ This finding is similar to findings in Beaudry and Guay (1996) and van Wincoop (1993).

${ }^{17}$ See Ingram, Kocherlakota, and Savin (1994a, 1994b), Cochrane (1994) and King (1995) for extensive discussions of the standard approach and its shortcomings. IKS (1994a), for example, forcefully argue that there is no way to get a definitive answer to the question of how much variation in output can be attributed to technology shocks. Our variance decomposition method is closely related to those employed in Ingram, Kocherlakota, and Savin (1994a), McGrattan (1994), Kouparitsas (1997), and Kose (1998).

${ }^{18}$ Our approach employs the familiar Choleski decomposition. It is possible of course to perform other decompositions, such as those employed in Clarida and Gali (1994) and other papers. However, the identification restrictions in these papers typically involve linkages between nominal and real variables, i.e., money shocks have no effect on output. Our setting involves only real shocks, and it is difficult to think of intuitive restrictions that would involve a shock having zero effect on one of our variables. Hence, we focus on the more traditional triangular decompositions. Pesaran and Shin (1998) and others have developed "generalized" variance decompositions, in which orthogonalized shocks are not required. However, one drawback of this approach is that the variance decompositions do not add up to 1 .
} 
preference shock is last - only that part of $\hat{\eta}_{t}$ uncorrelated with the other shocks is "assigned" to $\hat{\eta}_{t}$. We obtain the variance decomposition of output into the four exogenous shocks by running the following regression,

$$
y_{t}=\sum_{l=0}^{L} b_{r, l} \hat{r}_{t-l}+\sum_{l=0}^{L} b_{e z, l} e_{t-l}^{z}+\sum_{l=0}^{L} b_{e \delta, l} e_{t-l}^{\delta}+\sum_{l=0}^{L} b_{e \eta, l} e_{t-l}^{\eta}+\varepsilon_{t},
$$

which we can rewrite as:

$$
y_{t} \equiv y_{t}^{r}+y_{t}^{z}+y_{t}^{\delta}+y_{t}^{\eta}+\varepsilon_{t}
$$

where $\mathrm{L}$ is the number of lags, and $e_{t-l}^{z}, e_{t-l}^{\delta}$, and $e_{t-l}^{\eta}$ are the residuals from the regressions of $\hat{z}_{t-l}$ on the vector $\left[\begin{array}{llll}\hat{r}_{t} & \hat{r}_{t-1} \ldots . . \hat{r}_{t-L}\end{array}\right]$, of $\hat{\delta}_{t-l}$ on $\left[\begin{array}{llllllll}\hat{r}_{t} & \hat{r}_{t-1} & \ldots & \hat{r}_{t-L}, & \hat{z}_{t} & \hat{z}_{t-1} & \ldots & \hat{z}_{t-L}\end{array}\right]$, and of $\hat{\eta}_{t-l}$ on

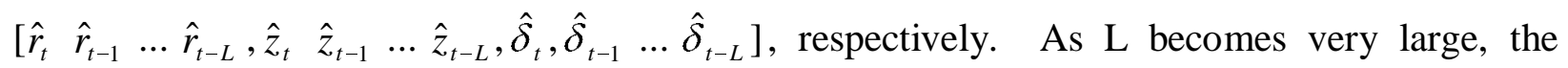
variance of $\varepsilon_{t}, \operatorname{var}\left(\varepsilon_{t}\right)$, goes to zero, because current and lagged values of the four shocks account for all of the variation in output fluctuations. For each regression we set the lag length at the smallest number for which $\operatorname{var}\left(\varepsilon_{t}\right)<0.01 \operatorname{var}\left(\mathrm{y}_{\mathrm{t}}\right)$. The fraction of the variance of output explained by each shock is then given by:

$$
q^{z}=\frac{\operatorname{var}\left(y_{t}^{z}\right)}{\operatorname{var}\left(y_{t}\right)}, q^{r}=\frac{\operatorname{var}\left(y_{t}^{r}\right)}{\operatorname{var}\left(y_{t}\right)}, q^{\delta}=\frac{\operatorname{var}\left(y_{t}^{\delta}\right)}{\operatorname{var}\left(y_{t}\right)}, q^{\eta}=\frac{\operatorname{var}\left(y_{t}^{\eta}\right)}{\operatorname{var}\left(y_{t}\right)}
$$

Hence, the sum of the contributions of the shocks is one. We follow this procedure for all twenty-four orderings, and then repeat it for five other macroeconomic variables. The results of our variance decompositions are presented in Table 6 . The table gives the maximum, median, and minimum percentage of variation in each variable that is explained by each shock. Note that for each variable and each shock, the range of variances is large, indicating a good deal of sensitivity to the ordering assumptions. For example, technology shocks explain as much as $78 \%$ of output variation, which occurs when it is ordered first, and as little as $9.5 \%$ of output variation, which occurs when it is ordered last.

The third column of the table suggests that interest rate shocks exert their largest effect on net exports and net foreign assets, and can account for over 50\% of the fluctuations in these variables. The median variance attributable to interest rates was about $35 \%$ for these two variables. The medians also indicate that interest rate shocks accounted for more variation in net 
foreign assets than the other shocks, and they accounted for more variation in net exports than all but the preference shock. Even when interest rates are ordered last, they still explain over $12 \%$ of the variation in net exports and net foreign assets. The table also shows that interest rate shocks can account for up to $22 \%-33 \%$ of the fluctuations in output, investment, consumption, and labor hours. The median variance attributable to interest rates is about $14 \%-23 \%$ for these four variables.

Examining the impact of the other shocks, we see that our results suggest that technology shocks tend to explain the lion's share of output and investment variation, and preference shocks tend to explain more consumption variation than do the other shocks. Depreciation shocks have their greatest impact on investment and labor hours. Our findings on the importance of depreciation and preference shocks mirror results in Ambler and Paguet (1994) and Stockman and Tesar (1995), who find that introducing depreciation (preference) shocks into a one-country (two-country) real business cycle model, respectively, improves the fit of the model to the data.

Our main results are not too sensitive to departures from the benchmark parameterization. For example, as the risk aversion coefficient increases from 1.5 to 5 , the percentage of output variance explained by the world real interest rate shock decreases. The drop occurs because the volatility of the backed-out interest rate shock declines. Changes in the elasticity of the adjustment cost and of the share of capital income in total income also do not have any major impact in the results. The contribution of the real interest rate to explaining net exports and net foreign assets exhibits similar ranges as those listed in Table 6.

At this point it is instructive to compare our results to those of Mendoza (1991), SchmittGrohe (1998) and Correia, Neves, and Rebelo (CNR, 1995) - especially the two former studies, because they were also based on Canadian data. We find that the world real interest rate shock can account for up to $33 \%, 57 \%$ and $62 \%$ of output, net foreign asset, and trade balance variation in Canada. By contrast, Mendoza (1991, p.809) finds that interest rate shocks have only "minimal" effects on model variables. Schmitt-Grohe (1998) uses impulse responses to assess the importance of interest rate shocks (driven by changes in U.S. output) to Canada. She finds that the interest rate transmission mechanism alone cannot generate sufficiently strong output and employment responses relative to the data. In addition, CNR conclude that interest rate shocks exert small effects on output, consumption, and hours worked. Hence, our results clearly suggest a much stronger role than previous studies for interest rate shocks in generating macroeconomic fluctuations in small open economies. 
Because our methodology is considerably different from their methodologies, there could be many reasons why our results could differ from theirs. Our estimated interest rate measure is quite different from the proxies that their shock processes are characterized from. We allow for more shocks than just interest rate and technology shocks. In addition, we do not take a stand on the relation between the shocks or on the orthogonality of the shocks. Nevertheless, we implement one sensitivity analysis to assess whether the way we generate our interest rate shocks or the way we calculate the contribution of these shocks to macroeconomic volatility is more important in driving our results. We engage in the same variance decomposition exercises, but we replace our interest rate measure with alternative interest rate measures, including the U.S. TBill rate, the S\&P 500 return, and a weighted average of several developed countries' interest rates. We use the same backed out preference, depreciation, and productivity shocks as in the original exercises. We find that that the contribution of interest rates to explaining macroeconomic volatility decreases. For example, the median contribution of interest rates to the volatility of net exports and of foreign assets is about $15 \%$, compared to about $35 \%$ in the original decompositions. However, the median contribution of interest rates to output and consumption volatility decreases only slightly, to $12 \%$ from $14 \%$ (output) and to $16 \%$ from $17 \%$ (consumption). If the contribution of interest rates had fallen to zero, then that would have suggested that the way we generate the interest rate shocks is important, and that the results are not driven by our multiple-ordering variance decompositions. If the contribution of interest rates had remained unchanged, then that would have suggested that our variance decompositions are important, and that the results are not driven by the way we generated the shocks. Our findings are between these two extremes, suggesting that our main results are due to both features of our methodology - the backed-out shocks and the multiple-ordering variance decompositions.

Despite the differences in methodology, however, there are several similarities in the results. The benchmark model in Mendoza (1991) involves only technology shocks. When interest rate shocks are added, the contribution to macroeconomic fluctuations is quite small. For example, the standard deviation of output rises from $2.81 \%$ to $2.84 \%$. This is consistent with our results when interest rate shocks are ordered last. We find that they account for only $0.21 \%$ of output fluctuations, and less than $7 \%$ of the fluctuations in consumption, hours, and investment. From impulse responses, CNR find that, compared to technology shocks, interest rate shocks exert a relatively larger effect on net exports and a relatively smaller effect on output. From our variance decompositions, we obtain this finding, as well. Our results suggest that while the 
median contribution of interest rate shocks to the volatility of output is about $15 \%$, its median contribution to the volatility of net exports is about 35\%. Finally, Mendoza (1991) finds that, as the standard deviation of interest rate shocks increases to about five times the standard deviation of technology shocks, fluctuations in output and investment also increase. The standard deviation of our interest rate shock is an even larger multiple of the standard deviation of our technology shock. We surmise this helps increase the fraction of output and investment fluctuations attributable to interest rates. ${ }^{19}$

Summarizing, we find that interest rate shocks can be important in explaining fluctuations - particularly fluctuations in net exports and net foreign assets - in a small open economy. This is in contrast to the results of several recent quantitative studies on this topic. However, our results are qualitatively similar to these results, indicating the presence of similar economic mechanisms at work. Also, our results become quantitatively similar to their results when interest rate shocks are ordered last in our variance decompositions.

\section{Conclusion}

Most models of small open economies posit several channels by which world shocks are transmitted to the small economy. Of these channels, the interest rate channel is often given special prominence. Hence, it is surprising that several recent quantitative analyses applying the standard real business cycle approach have found that fluctuations in world interest rates have little effect on domestic investment, output, net exports, and net foreign assets. In this paper we employ an alternative approach to quantitatively address the importance of interest rate shocks in a small open economy. The key point of departure is that we use the model and data on the endogenous variables to back out the exogenous shocks that are consistent with the model, while the standard approach posits statistical processes for the exogenous shocks (based on proxies of these shocks) and feeds these processes through the model to generate the endogenous variables that are consistent with the model. We view our approach as addressing difficulties in the standard approach arising from the question of the appropriate proxy for world real interest rates and from the singularity of the models typically employed. A second feature of our framework

\footnotetext{
${ }^{19}$ There is one additional similarity between Mendoza (1991) and our results. Mendoza's Table 5 shows that even when the correlation between technology shocks and interest rate shocks is \pm 0.9 , the moment properties of key variables are basically unchanged. We note that when the shocks are this highly correlated, variance decompositions that order interest rates first (second) will tend to attribute much (little) of the variation in output and other variables to interest rates.
} 
is that we deal with the fact that the exogenous shocks are correlated by performing variance decompositions for all possible orderings of the shocks.

We apply our approach to Canada, a country that has been studied quite thoroughly via the standard approach. Our findings indicate that world interest rate shocks can have large effects, particularly on net exports and net foreign assets, but also on output. Our sensitivity analysis indicates that both features of our methodology - the backed-out shocks and the multiple-ordering variance decompositions - are driving our findings. We conclude that the world real interest rate can be an important transmission mechanism of world business cycles to small open economies. Nevertheless, the results of the other recent research are qualitatively similar to our results, and quantitatively similar to the lower bound of our variance decompositions, occurring when the world real interest rate is ordered last.

In our model, we do not include fiscal and monetary policy shocks, which are important in understanding business cycle dynamics in open economies. It would be useful to apply this methodology to examine the role of these shocks in a more complex small open economy model. 


\section{REFERENCES}

Ambler S. and A. Paquet, 1994, "Stochastic depreciation and the business cycle," International Economic Review, vol. 35, no. 1, 101-116.

Backus, D. K., P. J. Kehoe, and F. E. Kydland, 1992, "Real business cycles," Journal of Political Economy, 100, 745-775.

Barro, R. and X. Sala-i-Martin, 1990, "World real interest rates," NBER Macroeconomics Annual, 15-61.

Baxter, M., 1995, "International trade and business cycles," in: Handbook of International Economics, Gene Grossman and Kenneth Rogoff (eds), Amsterdam: North Holland.

Baxter, M., and M. Crucini, 1993, "Explaining saving-investment correlations," American Economic Review, 83, 416-436.

Baxter, M., and R. King, 1998, "Productive externalities and business cycles," forthcoming European Economic Review.

Beauchemin, K. R., 1996, "Whither the stock of public capital?," working paper, University of Colorado at Boulder.

Beaudry, P. and A. Guay, 1996, "What do interest rates reveal about the functioning of real business cycle models?," Journal of Economic Dynamics and Control, 20, 1661-1682.

Clarida, R. and J. Gali, 1994, "Sources of real exchange rate fluctuations: How important are nominal shocks?" Carnegie-Rochester Conference Series on Public Policy, 41, 1-56.

Cochrane, J. H., 1994, "Shocks," Carnegie Rochester Conference Series on Public Policy, 41, 295-364.

Correia, I., J. C. Neves, and S.Rebelo, 1992, "Business cycles in Portugal: Theory and evidence," in J. Amaral, D. Lucena, and A. Mello (eds.) The Portuguese Economy Towards 1992. Kluwer, 1-64.

Correia, I., J. C. Neves, and S.Rebelo, 1995, "Business cycles in a small open economy," European Economic Review, 39, 1089-1113.

Gagnon, J.E. and M.D. Unferth, 1995, “Is there a world real interest rate?" Journal of International Money and Finance, 14, 845-855.

Greenwood, J., Z. Hercowitz, and G. Huffman, 1988, "Investment, capacity utilization and the real business cycle," American Economic Review, 78, 402-416.

Hall, R. E., 1986, "The role of consumption in economic fluctuations," in R J. Gordon, ed., The American business cycle: continuity and change, University of Chicago Press, 237-266. 
Hansen, L., 1982, "Large sample properties of generalized method of moment estimation," Econometrica, 50, 1029-1054.

Hercowitz, Z., 1986, "The real interest rate and aggregate supply," Journal of Monetary Economics, 18, 121-145.

Hodrick, R. J., and E. C. Prescott, 1997, "Postwar U. S. business cycles: an empirical investigation," Journal of Money, Credit , and Banking, 29, 1-16.

Ingram, B., 1995, "Recent advances in solving and estimating dynamic, stochastic macroeconomic models," in ed. K. Hoover, Macroeconometric Developments, Tensions and Prospects, Kluwer Academic Publishers, 15-47.

Ingram, B., N. Kocherlakota, and N. E. Savin, 1994a, "Explaining business cycles: A multiple shock approach," Journal of Monetary Economics, 34, 415-428.

Ingram, B., N. Kocherlakota, and N. E. Savin, 1994b, "Rational expectations shock estimation," mimeo, University of Iowa.

Ingram, B., N. Kocherlakota, and N. E. Savin, 1997, "Using theory for measurement: An analysis of the cyclical behavior of home production," Journal of Monetary Economics, $40,435-456$

Kim, S.H., and M.A. Kose, 1999, "Dynamics of open economy business cycle models: 'understanding the role of the discount factor'," manuscript, Brandeis University.

King, R.G., C. I. Plosser, and S. Rebelo, 1988, "Production, growth, and business cycles I: The basic neoclassical model," Journal of Monetary Economics, 21, 195-232.

King, R. G., C. I. Plosser, J. H. Stock, and M. W. Watson, 1991, "Stochastic trends and economic fluctuations," American Economic Review, 81, 819-840.

King, R. G., 1995, "Quantitative theory and econometrics," Federal Reserve Bank of Richmond Economic Quarterly, 81, 53-105.

Kose, M. A., 1998, "Explaining business cycles in small open economies," working paper, Brandeis University.

Kouparitsas, M., 1997, “North-South business cycles," working paper, Federal Reserve Bank of Chicago.

Lee, J. S., 1996, "Change of cyclical pattern in developing countries: evidence from Korea," working paper, The Bank of Korea.

McGrattan, E.R., 1994, "The macroeconomic effects of distortionary taxation," Journal of Monetary Economics, 33, 573-601. 
Mendoza, E. G., 1991, "Real business cycles in a small open economy," American Economic Review, 81, 797-889.

Obstfeld, M. and K. Rogoff, 1995, "The intertemporal approach to the current account," in: Handbook of International Economics, Gene Grossman and Kenneth Rogoff (eds), Amsterdam: North Holland.

Parkin, M., 1988, "A method for determining whether parameters in aggregative models are structural," Carnegie-Rochester Conference Series on Public Policy, 29, 215-252.

Pesaran, M.H., and Y. Shin, 1998, "Generalized impulse response analysis in linear multivariate models," Economics Letters, 58, 17-29.

Prescott, E. C., 1986, “Theory ahead of business cycle measurement," Federal Reserve Bank of Minneapolis Quarterly Review, 10, 9-22.

Sadka, J. C. and K. Yi, 1996, "Consumer durables, permanent terms of trade shocks, and the recent U.S. trade deficits," Journal of International Money and Finance, October, 797811.

Schmitt-Grohé S., 1998, "The international transmission of economic fluctuations," Journal International Economics, 44, 257-287

Senhadji, A., 1998, "Dynamics of the trade balance and the terms-of-trade in LDCs: The Scurve," Journal of International Economics, 46,105-131.

Smith, G. W., and S. E. Zin, 1997, "Real business cycle realizations," Carnegie-Rochester Series on Public Policy, 47, 243-280.

Stockman, A., and L. Tesar, 1995, "Tastes and Technology in a Two-Country Model of the Business Cycle: Explaining International Comovements," American Economic Review, $85,168-85$.

van Wincoop, E., 1993, "Real interest rates in a global bond economy," Working paper no. 52, Innocenzo Gasparini Institute for Economic Research.

Watson, M. W., 1991, "Measures of fit calibrated models," Journal of Political Economy, 101, 1011-1041. 


\section{Table 1}

Properties of the Real Interest Rate Measures

(Contemporaneous Correlations)

\begin{tabular}{ccccc}
\hline Int. rate & $r_{U S A}$ & ${ }_{W}$ & ${ } r_{S P}$ & $r_{L}$ \\
\hline$r_{U S A}$ & 1 & & & \\
$r_{W}$ & .85 & 1 & & \\
$r_{S P}$ & .12 & .23 & 1 & \\
$r_{L}$ & .95 & .76 & .01 & 1 \\
\hline
\end{tabular}

$r_{y}: \mathrm{y}=\mathrm{USA}$, U.S.A. T-Bill rate; $\mathrm{y}=\mathrm{W}$, weighted rate of developed economies; y=SP, S\&P 500 return; y=L, Libor rate. T-Bill rate, weighted rate, and Libor rate data are constructed using the IFS. The S\&P 500 return index is taken from the Ibbotson Associates Database. In constructing our ex ante real interest rates, we assume that inflation follows a random walk. We use changes in the CPI as our measure of inflation. The data is quarterly from 1963:1 to 1994:4. 


\section{Table 2}

\section{Policy Function Coefficients}

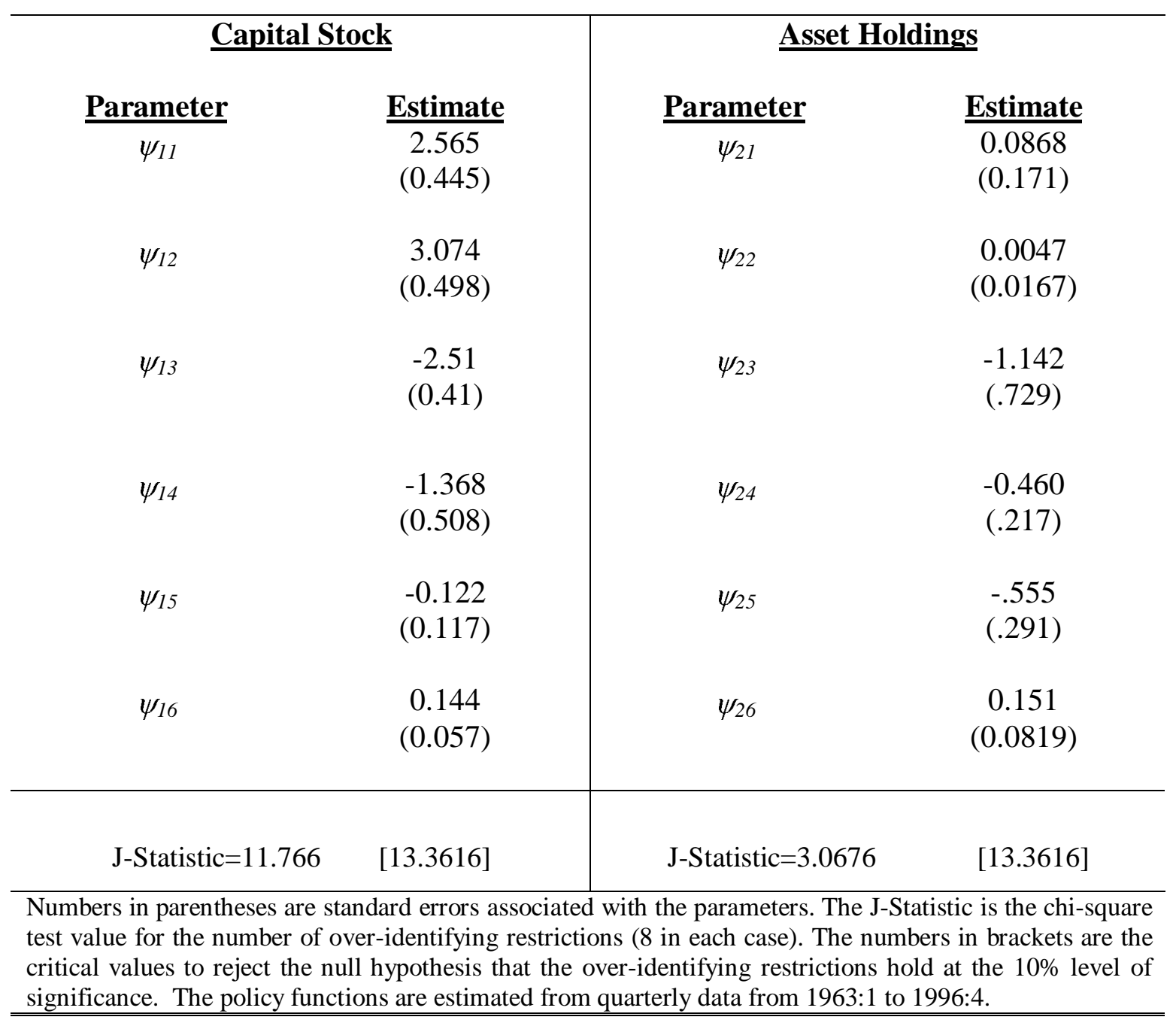




\section{Table 3}

\section{Properties of the Estimated Shocks}

(Volatility and Correlations)

\begin{tabular}{cccccc}
\hline Variable & Volatility & \multicolumn{3}{l}{ Correlation with } \\
\hline$r$ & 3.36 & 1.00 & $\delta$ & $\eta$ & $z$ \\
$\delta$ & 2.16 & -0.32 & 1.00 & & \\
$\eta$ & 0.47 & -0.17 & 0.43 & 1.00 & \\
$z$ & 0.46 & 0.38 & -0.65 & -0.37 & 1.00 \\
\hline
\end{tabular}

The technology $(\mathrm{z})$ and preference $(\eta)$ shocks are logged and then detrended by the Hodrick and Prescott (HP) (100) filter. The world interest rate (r) and depreciation ( $\delta$ ) shocks are in levels. Volatility is measured as the standard deviation of the (detrended) series.

\section{Table 4}

\section{Correlation with Macroeconomic Variables}

\begin{tabular}{lcccc}
\hline Correlation w/ & $r$ & $\delta$ & $\eta$ & $z$ \\
\hline Output & 0.24 & -0.05 & 0.06 & 0.72 \\
Consumption & 0.07 & -0.17 & 0.53 & 0.42 \\
Investment & -0.11 & 0.17 & 0.07 & 0.45 \\
Net Exports & 0.52 & -0.21 & -0.38 & 0.11 \\
Labor Hours & 0.05 & 0.48 & 0.61 & 0.11
\end{tabular}

The technology $(\mathrm{z})$ and preference $(\eta)$ shocks are logged and then detrended by the Hodrick and Prescott (HP) (100) filter. The world interest rate (r) and depreciation $(\delta)$ shocks are in levels. All macroeconomic variables, except net exports, are logged and then $\operatorname{HP}(100)$ filtered. Net exports is normalized by output, then $\operatorname{HP}(100)$ filtered. The data range from 1963:1 to 1996:4. 
Table 5

\section{Comparison of Real Interest Rate Shock with Alternative}

Interest Rate Measures

\begin{tabular}{|c|c|c|c|c|c|}
\hline & ${ }^{r}$ Model & $r_{U S A}$ & $r_{W}$ & $r_{S P}$ & $r_{L}$ \\
\hline & \multicolumn{5}{|c|}{$\underline{\text { Volatility }}$} \\
\hline & 3.36 & 2.70 & 2.74 & 11.04 & 2.68 \\
\hline & \multicolumn{5}{|c|}{ Correlation with Real Interest Rate Shock } \\
\hline & 1.00 & -0.09 & -0.11 & 0.00 & -0.08 \\
\hline & \multicolumn{5}{|c|}{ Correlation with Macroeconomic Variables } \\
\hline Output & 0.24 & -0.10 & -0.04 & 0.05 & -0.10 \\
\hline Consumption & 0.07 & -0.04 & 0.01 & 0.05 & -0.06 \\
\hline Investment & -0.11 & -0.11 & -0.07 & -0.06 & -0.10 \\
\hline Net Exports & 0.52 & 0.04 & 0.03 & 0.13 & 0.03 \\
\hline Labor Hours & 0.05 & -0.17 & -0.08 & 0.01 & -0.16 \\
\hline
\end{tabular}

$r_{y}: \mathrm{y}=\mathrm{USA}$, U.S.A. T-Bill rate; $\mathrm{y}=\mathrm{W}$, weighted rate of developed economies; $\mathrm{y}=\mathrm{SP}, \mathrm{S} \& \mathrm{P} 500$ return; $\mathrm{y}=\mathrm{L}$,

Libor rate. T-Bill rate, weighted rate, and Libor rate data are constructed using the IFS, and the S\&P 500 return index is taken from the Ibbotson Associates Database. Consumption, investment, and net exports are drawn from the IFS; for the construction of the labor hours series, see fn. 11. All macroeconomic variables, except net exports and the interest rate measures, are logged and then HP(100) filtered. Net exports is normalized by output, then HP(100) filtered. The interest rate measures are in levels. The data range from 1963:1 to 1996:4. 


\section{Table 6}

Variance Decompositions

\begin{tabular}{|c|c|c|c|c|c|}
\hline & Statistic & $r$ & $z$ & $\delta$ & $\eta$ \\
\hline \multirow[t]{2}{*}{ Output } & {$[\mathbf{m a x}, \mathbf{m i n}]$} & {$[33.39,0.21]$} & {$[78.22,9.47]$} & {$[40.97,6.22]$} & {$[39.78,1.11]$} \\
\hline & median & 14.47 & 49.10 & 20.65 & 14.55 \\
\hline \multirow[t]{2}{*}{ Consumption } & {$[\max , \min ]$} & {$[28.76,4.11]$} & {$[43.61,7.62]$} & {$[31.80,7.35]$} & {$[56.70,10.10]$} \\
\hline & median & 17.28 & 35.01 & 24.06 & 41.23 \\
\hline \multirow[t]{2}{*}{ Investment } & {$[\max , \min ]$} & {$[31.54,6.36]$} & {$[54.17,6.94]$} & {$[41.64,13.16]$} & {$[43.01,6.65]$} \\
\hline & median & 22.72 & 41.20 & 25.46 & 26.86 \\
\hline \multirow[t]{2}{*}{ Labor Hours } & {$[\max , \min ]$} & {$[21.76,2.55]$} & {$[41.49,5.83]$} & {$[47.91,12.96]$} & {$[50.76,10.87]$} \\
\hline & median & 13.51 & 23.70 & 31.09 & 31.47 \\
\hline \multirow[t]{2}{*}{ Net Exports } & {$[\max , \min ]$} & {$[62.17,14.64]$} & {$[31.08,4.16]$} & {$[38.14,6.55]$} & {$[59.81,11.60]$} \\
\hline & median & 34.37 & 14.22 & 11.59 & 35.67 \\
\hline \multirow[t]{2}{*}{ Net For. Assets } & {$[\max , \min ]$} & {$[56.78,12.21]$} & {$[39.57,2.47]$} & {$[32.03,7.74]$} & {$[52.23,9.30]$} \\
\hline & median & 35.02 & 23.82 & 13.83 & 30.07 \\
\hline \multicolumn{6}{|c|}{$\begin{array}{l}\text { In each cell, the share of the variable's variance explained by a particular shock is reported. max, min, and median refer to } \\
\text { the upper bound, lower bound, and median of the variance decompositions across all orderings. The technology (z) and } \\
\text { preference }(\eta) \text { shocks are first logged and then detrended by the Hodrick and Prescott (HP) (100) filter. The world interes } \\
\text { rate (r) and depreciation }(\delta) \text { shocks are in levels. Consumption, investment, and net exports series are drawn from the IFS } \\
\text { data, labor hours series is taken from the OECD Main Economic Indicators. All macroeconomic variables, except ne } \\
\text { exports and net foreign assets, are logged and then HP(100) filtered. Net exports and net foreign assets are normalized by } \\
\text { output, then HP (100) filtered. Data range from 1963:1 to 1996:4. }\end{array}$} \\
\hline
\end{tabular}



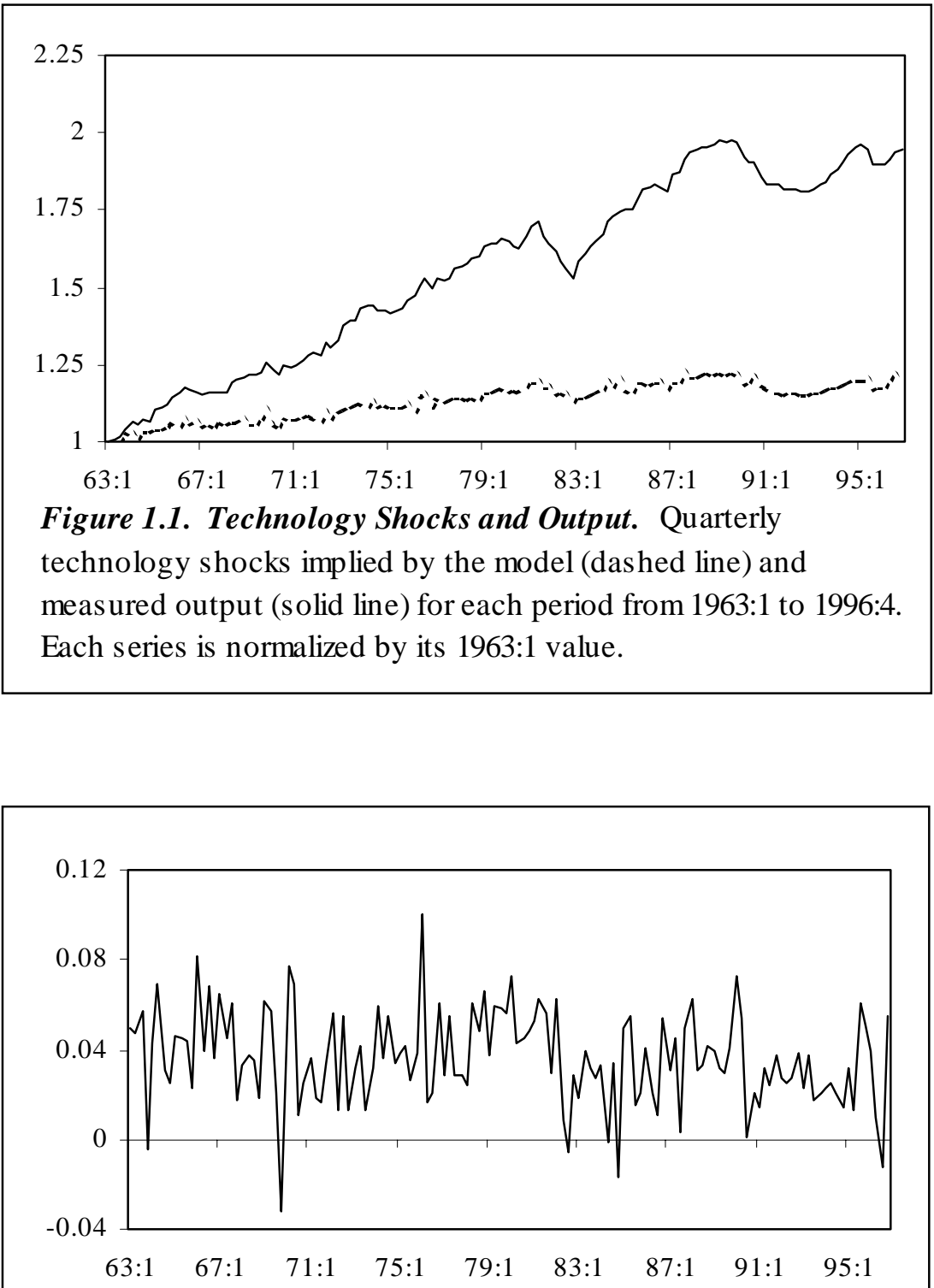

Figure 1.2. Depreciation Shocks. Quarterly depreciation shocks implied by the model from 1963:1 to 1996:4. 

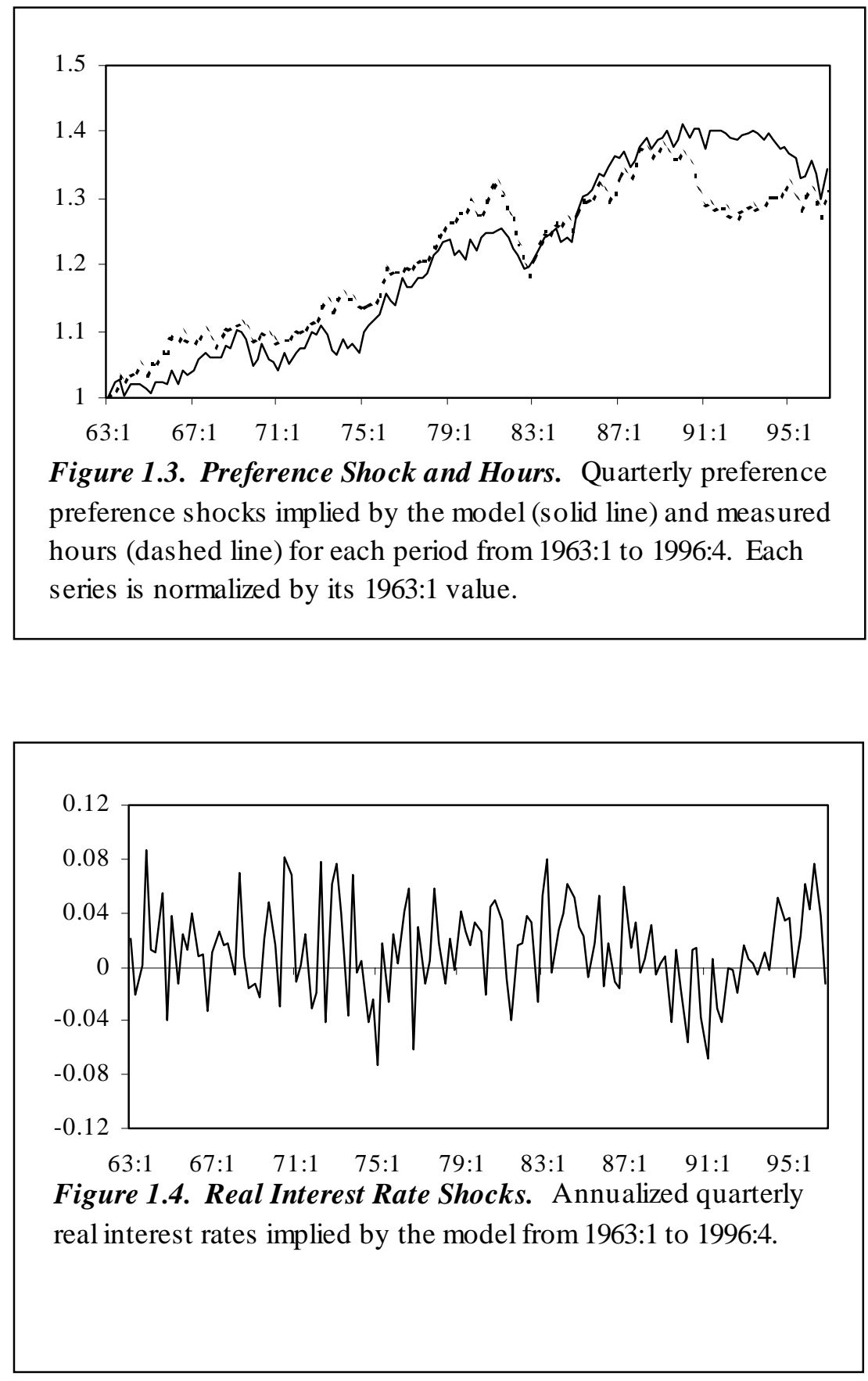